\title{
PENGARUH KUALITAS PELAYANAN TERHADAP KEPUASAN NASABAH PADA PT. BCA FINANCE CABANG BUKITTINGGI
}

\section{THE EFFECT OF SERVICE QUALITY ON CUSTOMER SATISFACTION IN PT. BCA FINANCE BRANCH BUKITTINGGI}

\author{
Dasep Suryanto \\ Sekolah Tinggi Ilmu Ekonomi Haji Agus Salim Bukittinggi \\ dasep.suryanto@gmail.com \\ Submit, 27-02-2019 Accepted, 03-04-2019 Publish, 03-04-2019
}

\begin{abstract}
Banking business is a service business that is based on the principle of trust so that the quality of service issues is a very decisive factor in the success of businesses managed by the company. The purpose of this study was to determine the effect of service quality on customer satisfaction at PT. BCA Finance Bukittinggi Branch. The sample was taken by researchers as many as 150 respondents who were customers of PT. BCA Finance Bukittinggi Branch, the analysis technique used in the study used Regression analysis. The results of this study indicate that: 1) Service Quality with dimensions of Physical Evidence, Reliability, Responsive Capability, Assurance and Empathy has a positive and significant influence on customer satisfaction. From the results of this study, it was suggested to the management of PT. BCA Finance Bukittinggi Branch to conduct periodic evaluations and research to improve service quality, especially in terms of Physical Evidence and Responsiveness to provide training in direct contact with customers, so as to minimize customer complaints and increase customer satisfaction.
\end{abstract}

Keywords: Service Quality, Customer Satisfaction

\begin{abstract}
ASBTRAK
Bisnis perbankan merupakan bisnis jasa yang berdasarkan pada azas kepercayaan sehingga masalah kualitas pelayanan menjadi faktor yang sangat menentukan dalam keberhasilan usaha yang dikelola oleh perusahaan. Tujuan dari penelitian ini adalah untuk mengetahui pengaruh kualitas layanan terhadap kepuasan pelanggan di PT. BCA Finance Cabang Bukittinggi. Sampel diambil oleh peneliti sebanyak 150 responden yang merupakan pelanggan PT. BCA Finance Cabang Bukittinggi, teknik analisis yang digunakan dalam penelitian menggunakan analisis Regresi. Hasil penelitian ini menunjukkan bahwa: 1) Kualitas Layanan dengan dimensi Bukti Fisik, Keandalan, Kemampuan Responsif, Jaminan dan Empati memiliki pengaruh positif dan signifikan terhadap kepuasan pelanggan. Dari hasil penelitian ini, disarankan kepada manajemen PT. BCA Finance Cabang Bukittinggi untuk melakukan evaluasi dan penelitian berkala untuk meningkatkan kualitas layanan, terutama dalam hal Bukti Fisik dan Responsif untuk memberikan pelatihan dalam kontak langsung dengan pelanggan, sehingga dapat meminimalkan keluhan pelanggan dan meningkatkan kepuasan pelanggan.
\end{abstract}

Kata Kunci: Kualitas Layanan, Kepuasan pelanggan 


\section{PENDAHULUAN}

Bank merupakan salah satu lembaga keuangan yang memiliki peranan penting dalam perekonomian suatu negara, karena hampir semua sektor yang berhubungan dengan kegiatan keuangan selalu membutuhkan jasa bank (Kasmir, 2002). Jasa-jasa bank merupakan penentu berjalanya perekonomian masyarakat. Dalam arti yang luas, sebuah bank dapat dianggap sentral dari suatu struktur keuangan yang kompleks. Sebagai intermediary, bank menghimpun dana masyarakat berupa simpanan dalam bentuk giro, deposito dan tabungan yang selanjutnya dana tersebut disalurkan kepada masyarakat berupa pinjaman atau kredit. Selain itu, bank dapat memberikan layanan berupa jasa-jasa lainnya berupa transfer, bank garansi dan lainnya sebagaimana kelaziman di dunia perbankan.

Bisnis perbankan merupakan bisnis jasa yang berdasarkan pada azas kepercayaan sehingga masalah kualitas pelayanan menjadi faktor yang sangat menentukan dalam keberhasilan usaha yang dikelola oleh perusahaan. Kualitas Pelayanan merupakan suatu bentuk penilaian konsumen terhadap tingkat layanan yang diterima (perceived service) dengan tingkat layanan yang diharapkan (expected service) (Kotler dan keller, 2007).

Kotler dan Keller (2007), mengungkapkan bahwa kualitas pelayanan adalah suatu cara kerja perusahaan yang berusaha mengadakan perbaikan mutu secara terus-menerus terhadap proses, produk dan service yang dihasilkan perusahaan. Sedangkan menurut Tjiptono (2008), kualitas pelayanan merupakan upaya pemenuhan kebutuhan dan keinginan konsumen serta ketepatan penyampaiannya dalam mengimbangi harapan konsumen. Oleh karena itu sistem pengelolaan wajib didasarkan prinsip kehati-hatian, agar kesehatan perusahaan tetap terjaga demi kepentingan masyarakat pada umumnya dan nasabah penyimpan dana pada khususnya. Pertumbuhan ekonomi terus berkembang menuntut eksistensi dari bank untuk melayani masyarakat.

Memiliki pelanggan yang puas tidaklah cukup, pelanggan haruslah sangat puas karena kepuasan pelanggan mengarah pada loyalitas (Bowen dan Chen, 2001). Untuk bertahan hidup di industri perbankan yang kompetitif, bank harus mengembangkan strategi baru untuk memuaskan pelanggan mereka. Membangun loyalitas pelanggan bukan merupakan pilihan dalam bisnis, ini satu-satunya cara membangun keunggulan kompetitif yang berkelanjutan. Keterkaitan antara kualitas pelayanan, kepuasan pelanggan, dan loyalitas pelanggan dapat memberikan ide-ide kreatif untuk meningkatkan pelayanan dalam rangka mendapatkan keuntungan kompetitif di sektor ritel perbankan (Siddiqi, 2011).

Dalam fungsi pemasaran, pelayanan yang berkualitas memegang peran sangat penting. Kualitas pelayanan yang baik merupakan satu hal yang sangat penting untuk meraih pasar. Kepuasan konsumen merupakan tingkat perasaan seseorang setelah membandingkan kinerja (hasil) yang dirasakan dengan harapan (Tjiptono, 1998). Menurut Kotler dan Keller (2007), kepuasan konsumen merupakan perasaan senang atau kecewa seseorang yang muncul setelah membandingkan antara persepsi/kesannya terhadap kinerja (hasil) suatu produk dan harapan-harapannya.

Salah satu faktor yang mempengaruhi kepuasan konsumen PT. BCA Finance Cabang Bukittinggi adalah kualitas pelayanan yang meliputi bukti fisik (tangible) seperti ruang 
kantor, tempat parkir dan ruang tunggu, kehandalan (reliability) pelayanan yang diberikan sesuai dengan yang dijanjikan dan memuaskan, daya tanggap (responsiveness) karyawan melayani dengan tepat kesulitan yang dihadapi konsumen, empati (emphaty) karyawan melayani konsumen dengan penuh perhatian dan jaminan (assurance) sehingga konsumen merasa aman melakukan transaksi di kantor PT. BCA Finance Cabang Bukittinggi. Bagi perusahaan suatu prinsip yang harus dipegang teguh setiap saat yaitu konsumen adalah raja. Prinsip ini berlaku dimanapun, kapanpun dan kepada siapapun. Ini berarti bahwa setiap perusahaan harus menempatkan kualitas pelayanan pada posisi terdepan atau ujung tombak dalam berbisnis.

Berdasarkan hal tersebut diatas, secara langsung akan mengakibatkan munculnya persaingan yang ketat di pasar khususnya antar lembaga pembiayaan. Munculnya berbagai perusahaan jasa lembaga pembiayaan di Kota Bukittinggi, seperti Adira Finance, ACC Finance, OTO Finance, FIF, Bussan Auto Finance dan mungkin masih banyak lagi yang akan bermunculan dengan tingkat persaingan yang semakin mengglobal, baik dari jenis kredit yang ditawarkan, sistem pelayanan yang diberikan dan strategi mendekati konsumen adalah menjadi tantangan bagi perusahaaan.

PT. BCA Finance Cabang Bukittinggi adalah sebuah perusahaan yang bergerak dibidang pembiayaan keuangan dengan berkonsentrasi pada pembiayaan kendaraan roda empat, yang harus mempertahankan dan meningkatkan jumlah konsumen yang sudah dimiliki saat ini. PT. BCA Finance merupakan salah satu lembaga pembiayaan yang paling diminati oleh para pembeli kendaraan roda empat berbayar kredit di Bukittinggi. Selama tahun 2012 sampai dengan tahun 2014 penjualan kendaraan roda empat oleh PT. BCAF mengalami naik turun.

Permasalahan pada PT. BCA Finance Cabang Bukittinggi menurut data laporan tahunan PT.BCA Finance Cabang Bukittinggi, jumlah konsumen kredit dari tahun 2016 sampai tahun 2018 bisa dilihat pada table berikut:

Tabel 1. Data Konsumen Kredit

\begin{tabular}{ccc}
\hline Tahun & $\begin{array}{c}\text { Jumlah } \\
\text { konsumen }\end{array}$ & Persentase \\
\hline 2016 & 327 & - \\
\hline 2017 & 641 & $96 \%$ \\
\hline 2018 & 451 & $29 \%$ \\
\hline
\end{tabular}

Sumber : PT.BCA Finance Cabang Bukittinggi

Dari tabel 1. diatas terlihat jumlah konsumen pada tahun 2017 terjadi kenaikan sebesar 96\%, dan pada tahun 2018 terjadi penurunan sebesar $29 \%$. Dalam menghadapi ketatnya persaingan dengan lembaga pembiayaan lainnya, PT. BCA Finance Cabang Bukittinggi perlu memperhatikan harapan dan penilaian konsumen terhadap kinerja pelayanan perusahaan agar memperoleh informasi mengenai faktor - faktor apa saja yang telah memenuhi harapan konsumen dan yang belum sesuai dengan harapan. Berdasarkan data dari tabel diatas, dapat dilihat permasalahannya yaitu adanya penurunan konsumen pada perusahaan ini. Dalam hal pelayanan, penulis melihat adanya tingkat penurunan konsumen pada PT.BCA Finance Cabang Bukittinggi. Hal ini disebabkan karena pelayanan kepada konsumen yang kurang baik dan kurang dalam menerapkan dimensi kualitas pelayanan dalam melayani konsumen.

Menurut Tjiptono (2008) secara sederhana kualitas dapat diartikan sebagai produk yang bebas cacat atau produk sesuai dengan standar. Kualitas mencerminkan semua dimensi penawaran produk yang menghasilkan manfaat (benefit) bagi pelanggan. 
Istilah nilai (value) seringkali digunakan untuk mengacu pada kualitas relatif suatu produk dikaitkan dengan harga produk bersangkutan. Pelanggan merupakan fokus utama dalam bisnis, karena tanpa pelanggan perusahaan tidak bisa memperoleh profit untuk menjalankan usahanya. Oleh karena itu, hal utama yang harus dilakukan adalah dengan memberikan pelayanan yang berkualitas sehingga tercipta kepuasan untuk mendapatkan pelanggan yang loyal pada perusahaan. Layanan yang berkualitas adalah layanan yang secara ekonomis menguntungkan dan secara prosedural mudah serta menyenangkan sehingga dapat menciptakan kepuasan.

Tjiptono (2008) menyebutkan bahwa model kualitas jasa yang popular dan hingga kini banyak dijadikan acuan dalam riset pemasaran adalah model ServQual (singkatan dari service quality) yang kembangkan oleh Parasuraman, Zeithaml, dan Berry. Servqual dibangun atas adanya perbandingan dua factor utama yaitu persepsi pelanggan terima (perception service) dengan layanan yang sesungguhnya diharapkan (expected service).

Parasuraman et al. (1988) mengidentifikasi lima dimensi dari SERVQUAL, yaitu: tangibles, reliability, responsiveness, assurance dan empathy. Kelima aspek kualitas jasa apabila diterapkan secara bersama akan dapat membangun layanan yang berkualitas prima dan memuaskan. Yee et al. dalam Siddiqi (2011) menyatakan kualitas pelayanan memiliki pengaruh positif dan signifikan pada kepuasan pelanggan. Dengan menjaga kualitas pelayanan maka dapat meminimalkan terjadinya ketidak puasan pelanggan. Untuk memberikan kepuasan kepada pelanggan, perusahaan harus melakukan perbaikan atau peningkatan kualitas pelayanan secara terus-menerus.
Bowen dan Chen (2001)
menemukan bahwa peningkatan kepuasan pelanggan yang kecil menyebabkan perubahan loyalitas pelanggan secara dramatis. Korelasi positif antara kepuasan dan loyalitas akan menimbulkan keinginan nasabah untuk merekomendasikan bank kepada orang lain. Sebagai konsekuensinya, bank dapat memiliki kesetiaan dari nasabahnya dan memiliki basis pelanggan stabil yang akhirnya dapat mengurangi biaya. Kepuasan pelanggan sebagai faktor yang menentukan penentu utama untuk mempertahankan pelanggan. Oleh karena itu, perusahaan harus selalu berusaha untuk memastikan bahwa pelanggan akan sangat puas.

Kepuasan adalah tanggapan terhadap pemenuhan keinginan konsumen.Ini adalah suatu penilaian bahwa fitur produk atau jasa, atau produk atau layanan itu sendiri, memberikan tingkat konsumsi yang menyenangkan terkait pemenuhan tersebut (Parasuraman et al., 2009).

Kepuasan adalah suatu sikap yang diputuskan berdasarkan pengalaman yang didapatkan. Kepuasan merupakan penilaian mengenai ciri atau keistimewaan produk, jasa, atau produk itu sendiri, yang menyediakan tingkat kesenangan konsumen berkaitan dengan pemenuhan kebutuhan konsumsi.

Kepuasan pelanggan adalah tingkat perasaan pelanggan setelah membandingkan antara apa yang dia terima dan harapannya (Umar, 2005). Seorang pelanggan, jika merasa puas dengan nilai yang diberikan oleh produk atau jasa, sangat besar kemungkinannya menjadi pelanggan dalam waktu yang lama. Menurut Philip Kotler dan Kevin Lane Keller yang dikutip dari buku Manajemen Pemasaran mengatakan bahwa kepuasan Pelanggan adalah perasaan senang atau kecewa seseorang yang muncul setelah membandingkan 
kinerja (hasil) produk yang dipikirkan terhadap kinerja yang diharapkan. Faktor-faktor yang mempengaruhi kualitas pelayanan yang dikembangkan parasuraman, Zeithalm dan Berry adalah tangible, reliability, assurance, responsiveness dan emphaty. Penerapan Total Quality Manajemen (TQM) yang diaplikasikan perusahaan pada awalnya adalah untuk memperbaiki mutu produk namun dalam perkembangannya perusahaan yang bergerak di bidang jasa atau pelayanan juga menerapkan TQM untuk memberikan kepuasan pelanggan. Inti dari Total Quality Manajemen ( TQM) adalah memberikan kepuasan kepada konsumen dengan memenuhi keinginan dan kebutuhannya serta menciptakan proses pelayanan yang mudah.

Kualitas pelayanan merupakan syarat kelangsungan hidup perusahaan, tingginya kualitas yang diberikan akan mencerminkan pada aspek kepuasan para pelanggan. Menurut Alma (2000) hal penting perusahaan dalam menjalankan usahanya adalah penerapan kualitas pelayanan sehingga tercapai kepuasan pelanggan yang pada akhirnya meningkatkan loyalitas konsumen dan tidak terbujuk untuk berpindah perusahaan lain.

Hal tersebut dikuatkan dari Lupiyoadi dan Hamdani (2006) yang menyatakan bahwa kualitas memiliki hubungan yang erat dengan kepuasan pelanggan. Salah satu faktor yang menentukan kepuasan pelanggan adalah persepsi pelanggan mengenai kualitas pelayanan yang terdiri dari lima dimensi yaitu bukti fisik, keandalan, daya tanggap, jaminan, empati. Menurut Kotler dan Keller (2007), kepuasan pelanggan merupakan perasaan senang atau kecewa seseorang yang muncul setelah membandingkan kinerja (hasil) produk yang dipikirkan terhadap kinerja (atau hasil). Menurut Tjiptono (2008) ada konsep inti mengenai objek pengukuran, berikut indikator kepuasan Pelanggan: a.Kepuasan pelanggan keseluruhan (overal customer satisfaction) Pelanggan langsung ditanya seberapa puas dengan produk atau jasa. Kepuasan diukur berdasar produk atau jasa perusahaan bersangkutan dan membandingkan dengan tingkat kepuasan keseluruhan terhadap produk atau jasa pesaing. b.Minat pembelian ulangKepuasan pelanggan diukur bedasar perilaku dengan jalan menanyakan pelanggan apakah akan berbelanja atau menggunakan jasa perusahaan lagi. c. Kesediaan untuk merekomendasi Dalam kasus produk yang pembelian ulangnya relatif lama atau bukan hanya terjadi satu kali pembelian (seperti pembelian mobil, asuransi jiwa, tur keliling) kesediaan pelanggan untuk merekomendasikan produk kepada teman atau keluarga.

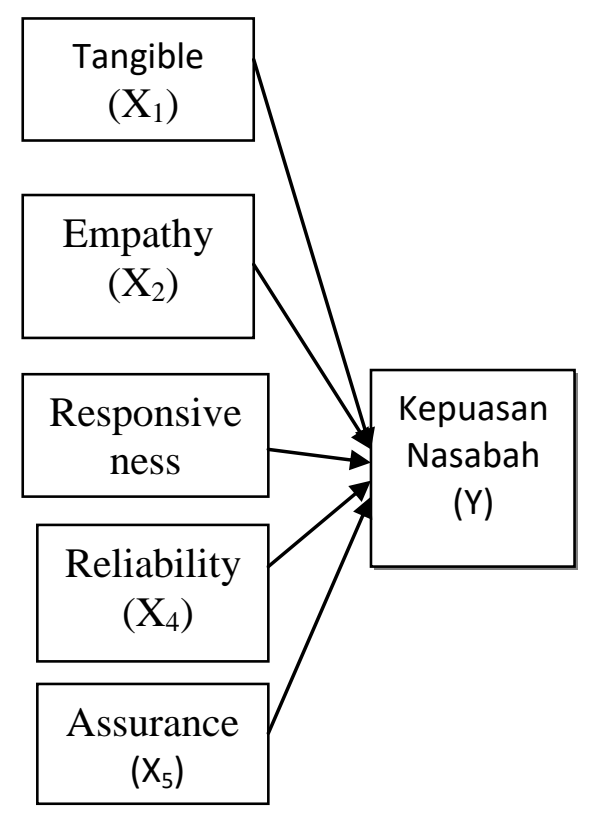

\section{Gambar 1. Kerangka Pemikiran Teoritis}


Dari penjabaran tentang kualitas pelayanan, loyalitas nasabah dan kepuasan nasabah yang telah diuraikan di atas maka hipotesis pada penelitian ini sebagai berikut :

H1: Dimensi Bukti Fisik (Tangibles) mempunyai pengaruh yang positif dan signifikan terhadap kepuasan nasabah pada PT.BCA Finance Cabang Bukittinggi.

H2: Dimensi Keandalan (Reliability) mempunyai pengaruh yang positif dan signifikan terhadap kepuasan nasabah pada PT.BCA Finance Cabang Bukittinggi.

H3: Dimensi Daya Tanggap (responsiveness) mempunyai pengaruh yang positif dan signifikan terhadap kepuasan nasabah pada PT.BCA Finance Cabang Bukittinggi.

H4 : Dimensi Jaminan (Assurance) mempunyai pengaruh yang positif dan signifikan terhadap kepuasan nasabah pada PT.BCA Finance Cabang Bukittinggi.

H5: Dimensi Empati (Empaty) mempunyai pengaruh yang positif dan signifikan terhadap kepuasan nasabah pada PT.BCA Finance Cabang Bukittinggi.

\section{METODE PENELITIAN}

Data dalam penelitian ini, diperoleh dan dikumpulkan pada suatu saat di tahun 2018 dengan tempat pengambilan data di wilayah kerja PT. BCA Finance Cabang Bukittinggi. Penelitian ini menggunakan jenis data primer dimana data diperoleh dengan menyebarkan kuisioner. Pengambilan sampel dilakukan dengan menggunakan metode Probability sampling.

Metode kuesioner adalah sejumlah pertanyaan secara tertulis yang akan dijawab oleh responden penelitian, agar peneliti memperoleh data lapangan/empiris untuk memecahkan masalah penelitian dan menguji hipotesis yang telah ditetapkan (Supardi, 2005).

Dalam rangka mendukung penelitian ini, maka peneliti mengembangkan tipe investigasi penelitian yang bersifat kausalitas karena didasarkan pada hubungan sebab akibat yang dimilik antar variabel yang di uji dalam penelitian.

Variabel dalam penelitian ini dapat diklasifikasikan kedalam dua kategori yaitu terdiri dari variabel dependen dan variabel independen dengan menggunakan alat analisa adalah Analisis Regresi. Adapun variabel dependen dalam penelitian ini adalah kualitas pelayanan sedangkan variabel terikat yang dikemukakan dalam penelitian yaitu kepuasan nasabah. Skala likert digunakan untuk mengukur berbagai variabel yang dikemukakan, hal ini didasarkan pada alasan bahwa penelitian sebelumnya terkait berbagai variabel dalam penelitian ini juga menggunakan skala likert untuk mengukur setiap variabel.

$$
\text { Kualitas pelayanan telah }
$$
dikonseptualisasikan sebagai perbedaan antara harapan pelanggan mengenai pelayanan yang akan diterima dan persepsi jasa yang diterima (Parasuramanet al. 1998). Kualitas pelayanan merupakan sebuah konsep multidimensi (Parasuraman et al. dalam Bloemer et al. 1998). Dimensi kualitas pelayanan dapat diidentifikasi melalui penelitian yang dilakukan oleh Parasuraman et al. yang dikenal sebagai SERVQUAL (Kotler dan Keller, 2007), sebagai berikut: 1) bukti fisik (Tangibles), 2) keandalan (Reliability), 3) daya tanggap (Responsiveness), 4) jaminan (Assurance), 5) empati (Empaty)

Fornel, dkk dalam Tjiptono (2008) menunjukkan enam konsep inti dalam mengukur kepuasan pelanggan pada bidang jasa, yaitu terdiri atas: 
1. Kepuasan pelanggan keseluruhan

2. Dimensi kepuasan pelanggan (Overall customer satisfaction)

3. Konfirmasi harapan (Confirmation of expectation)

4. Minat pembelian ulang (Repurchase intent)

5. Kesedian untuk merekomendasikan (Willingness to recommended)

6. Ketidakpuasan pelanggan (Customer dissatisfaction)

Sumber data yang digunakan dalam penelitian ini terdiri dari data primer dan data sekunder. Data primer berupa kegiatan terkait studi lapangan yang dilakukan untuk memperoleh data dari para responden yang menjadi subjek dalam penelitian ini.

Data sekunder menggunakan sumber data yang berasal dari publikasi dokumen yang tersedia di bank dan sumber lainnya. Teknik pengumpulan data yang dikembangkan dalam penelitian ini yaitu menggunakan kuisioner. Teknik kuisioner yang dilakukan meliputi penyebaran daftar pernyataan yang harus diisi oleh para responden guna mendukung penelitian yang dilakukan. Skala likert 5 Point digunakan dalam kuisioner untuk mengukur berbagai instrumen yang dikemukakan

Pada penelitian ini, besarnya sampel disesuaikan dengan model analisis yang digunakan yaitu regresi linear berganda. Berkaitan dengan hal tersebut, ukuan sampel untuk regresi yang menggunakan model estimasi maximum likelihood estimation (MLE) adalah 100-200 sampel (Ghozali, 2008). Ukuran sampel dalam penelitian harus memiliki jumlah sampel minimum lima kali jumlah pertanyaan yang dianalisis. Populasi dalam penelitian ini adalah nasabah PT. BCA Finance Cabang Bukittinggi terdiri dari berbagai latar belakang diantaranya yaitu Jenis Kelamin, Usia, Pendidikan dan pekerjaan, dengan jumlah populasi sebanyak 3984 orang nasabah.

Untuk menentukan ukuran sampel yang akan diteliti dengan menggunakan rumus slovin dengan batas toleransi $10 \%$, sehingga sampel dalam penelitian ini sebanyak 150 orang nasabah.

Jenis statistik yang digunakan untuk analisis data dalam penelitian ini adalah statistik deskriptif yang berfungsi untuk mencari deskripsi berbagai variabel yang dikemukakan. Dengan menggunakan statistik deskriptif, data yang diperoleh akan dikumpulkan dan dimasukkan dalam bentuk tabel dengan menggunakan bantuan program Microsoft Excel dan kemudian data diolah dengan menggunakan program SPSS.20 untuk mendapatkan presentase dan frekuensi data.

Instrumen penelitian berupa kuisioner dikemukakan Parasuraman, Zeithaml dan Berry tentang skala SERVQUAL. Data dari kuisioner dengan menggunakan skala Likert yang berupa data ordinal. Penentuan skor item pertanyaan diukur dengan skala Likert, yaitu skala yang berhubungan dengan pernyataan sikap terhadap sesuatu. Pengukuran dengan skala Likert terdiri lima pilihan jawaban, yaitu sangat setuju bernilai 5 , setuju bernilai 4, netral bernilai 3,tidak setuju bernilai 2 dan sangat tidak setuju bernilai 1 .

Menurut Ghazali (2008), analisis regresi linear berganda dimaksudkan untuk menguji sejauh mana arah pengaruh variabel-variabel independen terhadap variabel dependen. Variabel independen dalam penelitian ini adalah bukti langsung, keandalan, daya tanggap, jaminan dan empati dangan variabel dependen adalah kepuasan konsumen. Berikut persamaan regresi 
linear berganda untuk pengujian hipotesis yaitu:

$$
\begin{aligned}
\mathrm{Y}=\mathrm{a}+\mathrm{b} 1 \mathrm{X} 1+\mathrm{b} 2 \mathrm{X} 2+\mathrm{b} 3 \mathrm{X} 3+\mathrm{b} 4 \mathrm{X} 4+ \\
\mathrm{b} 5 \mathrm{X} 5+\mathrm{e}
\end{aligned}
$$

Dimana :

$\mathrm{Y}=$ Kepuasan Konsumen,

$\mathrm{X} 1$ = Bukti Fisik,

$\mathrm{X} 2$ = Keandalan,

X3 = Daya Tanggap,

$\mathrm{X} 4$ = Jaminan,

X5 = Empati,

$\mathrm{a}=$ Konstanta (Intercept),

b1,b2,b3,b4,b5, = Koefisien Regresi

(Parameter)

$\mathrm{e}=$ Faktor Kesalahan

Menurut Ghozali (2008), uji t

pada dasarnya menunjukkan seberapa jauh pengaruh suatu variabel bebas yang dalam hal ini bukti langsung / bukti fisik, keandalan, daya tanggap, jaminan dan empati secara parsial dapat mempengaruhi variabel terikat yaitu kepuasan konsumen. Untuk mengetahui kebenaran koefisien jalur, dilakukan pengujian hipotesis dengan uji $\mathrm{F}$ untuk pengujian secara keseluruhan variabel penyebab terhadap variable akibat. Dan uji $t$ untuk pengujian secara parsial variabel penyebab terhadap variabel akibat (Sitepu, 1994).

\section{HASIL DAN PEMBAHASAN}

Hasil penelitian dimulai dengan menguji validitas dan reabilitas, memberikan deskripsi variabel-variabel penelitian, setelah itu dilanjutkan dengan pengujian hiootesis dan mencari besar pengaruh variabel-variabel penelitian tersebut.

\section{Uji Validitas}

Dengan uji validitas, jika hasil uji terhadap alat ukurnya bermakna valid, maka hasil perhitungan dan analisis data juga akan valid atau diakui dan dapat diterima. Sugiyono (2007) menyatakan bahwa syarat minimum untuk dianggap memenuhi syarat validitas adalah $r$ hitung $>r$ tabel, $r$ tabel pada penelitian ini adalah 0,1362. Jadi, apabila diperoleh $r$ hitung lebih besar dari 0,1339 maka butir pernyataan dalam instrumen penelitian dinyatakan valid. Berdasarkan hasil uji validitas butir pernyataan yang mengukur masingmasing variabel penelitian yaitu : Kualitas Pelayanan (X), Kepuasan Nasabah (Y) adalah valid. Hal ini disebabkan karena semua butir pernyataan memiliki nilai corrected item - total correlation di atas 0,1339

\section{Uji Realibilitas}

Untuk menguji reliabilitas atau kehandalan Kualitas Pelayanan (X) , Kepuasan Nasabah (Y). digunakan nilai croanbach's alpha minimal 0,60. (Nunnaly dalam Ghozali, 2013). Berdasarkan hasil reliabilitas terhadap variabel penelitian. bahwa nilai croanbach's alpha untuk semua variabel dalam penelitian ini memiliki nilai croanbach's alpha di atas 0,60, dengan demikian dapat diinterperstasikan bahwa semua variabel adalah reliable atau andal. Dengan kata lain, semua instrumen pernyataan yang dipergunakan adalah stabil dan konsisten dalam mengukur masing-masing variabel penelitian.

\section{Uji Heteroskedastisitas}

Uji Heteroskedastisitas pada penelitian ini tidak terdapat pola yang jelas, yang mana titik menyebar di atas dan dibawah angka 0 (nol) pada sumbu Y, maka dapat disimpulkan bahwa tidak terdapat heteroskedastisitas.

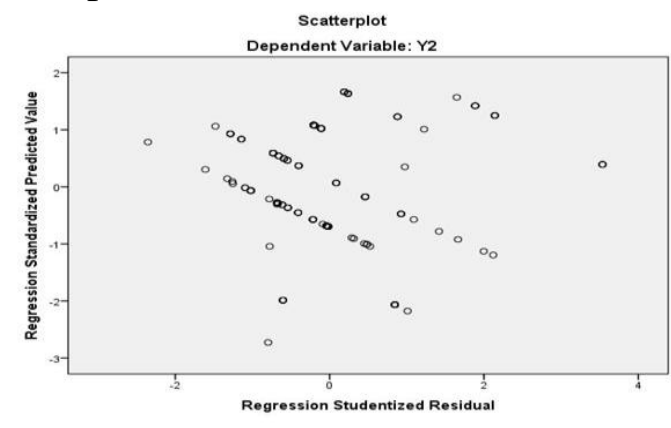

$$
\begin{aligned}
& \text { Gambar } 1 \text { Hasil Uji } \\
& \text { Heterokedastisitas }
\end{aligned}
$$




\section{Analisa Regresi}

Untuk menganalisis pola hubungan kausal antar variabel, dengan tujuan untuk mengetahui pengaruh langsung dan tidak langsung, baik secara serempak maupun secara sendirisendiri beberapa variabel bebas terhadap sebuah variabel terikat dengan menggunakan analisa regresi.

Tabel 2 Hasil SPSS Analisis Regresi Linear Berganda

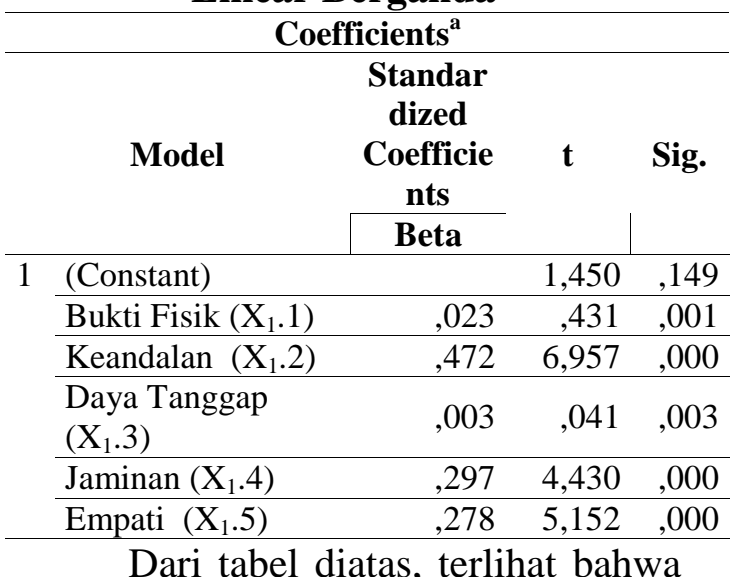

kualitas pelayanan berupa bukti fisik, keandalan, daya tangkap, jaminan dan empati berpengaruh signifikan terhadap kepuasan nasabah.

\section{Pengaruh dimensi Bukti Fisik (Tangible) terhadap Kepuasan nasabah PT. BCA Finance Cabang Bukittinggi.}

Berdasarkan hasil analisa regresi menunjukkan bahwa Dimensi Bukti Fisik (Tangible) $\left(\mathrm{X}_{1} .1\right)$ berpengaruh signifikan terhadap Kepuasan Nasabah $\left(\mathrm{X}_{2}\right)$ pada PT. BCA Finance Cabang Bukittinggi.

Dari hasil analisis diketahui bahwa Dimensi Bukti Fisik (Tangible) memberikan kontribusi terhadap Kepuasan Nasabah sebesar 2,3\% . Hal ini dapat diartikan bahwa dimensi bukti fisik mempengaruhi kepuasan nasabah dalam pengaruh kualitas layanan dapat memberikan acuan pada PT. BCA Finance Cabang Bukittinggi untuk tetap menjaga bukti fisik tersebut dalam kegiatan pelayanan sehingga nasabah yang dilayani dapat dipuaskan.

\section{Pengaruh dimensi Keandalan (Reliability) terhadap Kepuasan nasabah PT. BCA Finance Cabang Bukittinggi.}

Berdasarkan hasil analisa regresi menunjukkan bahwa Dimensi Keandalan (Reliability) ( $\left.\mathrm{X}_{1} .2\right)$ berpengaruh signifikan terhadap Kepuasan Nasabah $\left(\mathrm{X}_{2}\right)$ pada PT. BCA Finance Cabang Bukittinggi. Dari hasil analisis diketahui bahwa Dimensi Keandalan (Reliability) memberikan kontribusi terhadap Kepuasan Nasabah sebesar 47,2\% . Hal ini dapat diartikan bahwa dimensi keandalan mempengaruhi kepuasan nasabah dalam pengaruh kualitas layanan dapat memberikan acuan yang sangat besar pada PT. BCA Finance Cabang Bukittinggi untuk tetap menjaga keandalan tersebut dalam kegiatan pelayanan sehingga nasabah yang dilayani dapat merasa sesuai pengarapannya.

Pengaruh dimensi Daya Tanggap (Responsiveness) terhadap Kepuasan nasabah PT. BCA Finance Cabang Bukittinggi.

Berdasarkan hasil analisa jalur pengaruh Dimensi Daya Tanggap (Responsiveness) terhadap Kepuasan nasabah menunjukkan adanya pengaruh yang signifikan antara kedua variabel tersebut. Hasil analisis menunjukkan bahwa Dimensi Daya Tanggap (Responsiveness) ( $\left.\mathrm{X}_{1} .3\right)$ berpengaruh signifikan terhadap Kepuasan Nasabah $\left(\mathrm{X}_{2}\right)$ pada PT. BCA Finance Cabang Bukittinggi. Dari hasil analisis diketahui bahwa Dimensi Daya Tanggap (Responsiveness) memberikan kontribusi terhadap Kepuasan Nasabah sebesar $0,3 \%$. Hal ini dapat diartikan bahwa dimensi daya tanggap mempengaruhi kepuasan nasabah dalam pengaruh kualitas layanan dapat 
memberikan acuan pada PT. BCA Finance Cabang Bukittinggi untuk tetap menjaga daya tanggap tersebut dalam kegiatan pelayanan sehingga nasabah yang dilayani dapat merasa sesuai pengarapannya.

\section{Pengaruh dimensi Jaminan (Assurance) terhadap Kepuasan nasabah PT. BCA Finance Cabang Bukittinggi.}

Berdasarkan hasil analisa jalur pengaruh Dimensi Jaminan (Assurance) terhadap Kepuasan nasabah menunjukkan adanya pengaruh yang signifikan antara kedua variabel tersebut. Hasil analisis menunjukkan bahwa Dimensi Jaminan (Assurance) $\left(\mathrm{X}_{1} .4\right)$ berpengaruh signifikan terhadap Kepuasan Nasabah $\left(\mathrm{X}_{2}\right)$ pada PT. BCA Finance Cabang Bukittinggi.

Dari hasil analisis diketahui bahwa Dimensi Jaminan (Assurance) memberikan kontribusi terhadap Kepuasan Nasabah sebesar 29,7 \% . Hal ini dapat diartikan bahwa dimensi jaminan mempengaruhi kepuasan nasabah dalam pengaruh kualitas layanan dapat memberikan acuan pada PT. BCA Finance Cabang Bukittinggi untuk tetap menjaga dimensi jaminan tersebut dalam kegiatan pelayanan sehingga nasabah yang dilayani dapat merasa sesuai pengarapannya.

Pengaruh dimensi Empati (Emphaty) terhadap Kepuasan nasabah PT. BCA Finance Cabang Bukittinggi.

Berdasarkan hasil analisa jalur pengaruh Dimensi Empati (Emphaty) terhadap Kepuasan nasabah menunjukkan adanya pengaruh yang signifikan antara kedua variabel tersebut. Hasil analisis menunjukkan bahwa Dimensi Empati (Emphaty) $\left(\mathrm{X}_{1} .5\right)$ berpengaruh signifikan terhadap Kepuasan Nasabah $\left(\mathrm{X}_{2}\right)$ pada PT. BCA Finance Cabang Bukittinggi. Dari hasl analisis diketahui bahwa Dimensi Empati (Emphaty) memberikan kontribusi terhadap Kepuasan Nasabah sebesar 27,8\% . Hal ini dapat diartikan bahwa dimensi empati mempengaruhi kepuasan nasabah dalam pengaruh kualitas layanan dapat memberikan acuan pada PT. BCA Finance Cabang Bukittinggi untuk tetap menjaga dimensi empati tersebut dalam kegiatan pelayanan.

Dari penjelasan diatas, terlihat bahwa ke lima (5) Dimensi Kualitas Pelayanan berupa Bukti Fisik, Keandalan, Daya Tangap, Jaminan dan Empati berpengaruh siginifikan terhadap Kepuasan Nasabah. Hasil penelitian ini sesuai dengan penelitian yang dilakukan oleh Ramdhani et al. (2011) yang menyatakan ada hubungan positif dan signifikan antara kualitas pelayanan dengan kepuasan pelanggan. Penelitian tersebut sejalan dengan Naeem dan Saif (2009) yang menemukan bahwa kepuasan pelanggan adalah hasil dari kualitas pelayanan. Menurut Bedi dalam Ming et al. (2010) pengiriman layanan yang berkualitas tinggi adalah suatu keharusan untuk mencapai kepuasan pelanggan.

\section{PENUTUP}

\section{Kesimpulan}

Berdasarkan penelitian yang telah dilakukan, maka dapat ditarik beberapa kesimpulan antara lain:

1. Bukti Fisik (Tangible) memiliki pengaruh lansung yang siginifikan dan positif terhadap kepuasan. Penelitian ini menyimpulkan bahwa semakin baik Bukti Fisik (Tangible) yang diterapkan pada nasabah PT. BCA Finance Cabang Bukittinggi maka Kepuasan akan semakin baik. Demikian pula sebaliknya, semakin buruk Bukti Fisik (Tangible) yang diterapkan pada nasabah PT. BCA Finance Cabang Bukittinggi maka Kepuasan akan semakin buruk. 
2. Keandalan (Reliability) memiliki pengaruh langsung yang signifikan dan positif terhadap Kepuasan. Penelitian ini menyimpulkan bahwa semakin baik Keandalan (Reliability) yang diterapkan pada nasabah PT. BCA Finance Cabang Bukittinggi maka Kepuasan akan semakin baik. Demikian pula sebaliknya, semakin buruk Keandalan (Reliability) yang diterapkan pada nasabah PT. BCA Finance Cabang Bukittinggi maka Kepuasan akan semakin buruk.

3. Daya Tanggap (Responsiveness) memiliki pengaruh langsung yang signifikan dan positif terhadap Kepuasan. Penelitian ini menyimpulkan bahwa semakin baik Daya Tanggap (Responsiveness) yang diterapkan pada nasabah PT. BCA Finance Cabang Bukittinggi maka Kepuasan akan semakin baik. Demikian pula sebaliknya, semakin buruk Daya Tanggap (Responsiveness) yang diterapkan pada nasabah PT. BCA Finance Cabang Bukittinggi maka Kepuasan akan semakin buruk.

4. Jaminan (Assurance) memiliki pengaruh langsung yang signifikan dan positif terhadap Kepuasan. Penelitian ini menyimpulkan bahwa semakin baik Jaminan (Assurance) yang diterapkan pada nasabah PT. BCA Finance Cabang Bukittinggi maka Kepuasan akan semakin baik. Demikian pula sebaliknya, semakin buruk Jaminan (Assurance) yang diterapkan maka Kepuasan akan semakin buruk.

5. Empati (Emphaty) memiliki pengaruh langsung yang signifikan dan positif terhadap Kepuasan. Penelitian ini menyimpulkan bahwa semakin baik Empati (Emphaty) yang diterapkan pada nasabah PT. BCA Finance Cabang Bukittinggi maka Kepuasan akan semakin baik.
Demikian pula sebaliknya, semakin buruk Empati (Emphaty) yang diterapkan pada nasabah PT. BCA Finance Cabang Bukittinggi maka Kepuasan akan semakin buruk.

\section{Saran}

Berdasarkan kesimpulan diatas, maka dapat dikemukakan saran sebagai berikut: Bagi PT. BCA Finance Cabang Bukittinggi

1. PT. BCA Finance Cabang Bukittinggi, agar meningkatkan kualitas pelayanan supaya konsumen yang telah ada tetap merasa puas dan loyal terhadap perusahaan, serta mampu menarik konsumen yang baru.

2. PT. BCA Finance Cabang Bukittinggi lebih meningkatkan lagi kualitas pelayanan dari segi reliability, responsiveness, empathy dan tangible ke tahap yang lebih baik agar dapat memberikan kontribusi yang tinggi terhadap kepuasan konsumen kredit.

\section{DAFTAR PUSTAKA}

Bowen, J.T. \& Chen, S.L. (2001). The relationship between customer loyalty and customer satisfaction.

International Journal of Contemporary Hospitality Management 13(5): 213-217.

Ghozali, I. (2008). Model Persmaan Struktural : Konsep dan Aplikasi dengan Program AMOS 16.0. Semarang: Badan Penerbit Universitas Diponegoro

Kasmir. (2002). Dasar-dasar Perbankan. Jakarta: Rajawali Pers

Kotler, P. dan Keller, K.L. (2007). Manajemen Pemasaran. Jilid 1 dan 2. Jakarta: PT Indeks

Parasuraman, A., Zethaml. V.A., and Berry, L. (1988). SERQUAL: Multiple-item scale or Measuring consumer Perceptions 
of Service Quality, Journal of Retailing. 64(1):12-40.

Siddiqi, K.O. (2011). Between Service Quality Attributes, Customer Satisfaction and Customer Loyalty in the Retail Banking Sector in Bangladesh, International Journal of Business and Management, 6 (3) : 12 -36

Sugiyono. (2013). Metode Penelitian Kuantitatif, Kualitatif dan $R \& D$. Bandung: Alfabeta. 102

Tjiptono, F. (2008). Manajemen Jasa. Edisi Keempat. Yogyakarta: Andi Offet. 